\title{
Control Approaches against Vascular Wilt Disease of Elaeis guineensis Jacq. Caused by Fusarium oxysporum f. sp. elaeidis.
}

\author{
Godswill Ntsomboh Ntsefong (Corresponding author) \\ Specialized Centre for Oil Palm, Research (IRAD-CEREPAH) of La Dibamba. \\ P. O. Box 243 Douala, Cameroon
}

$\&$

Faculty of Science, Department of Plant Biology

University of Yaounde I, B. P. 812 Yaounde, Cameroon

Tel: 237-79-94-1910 / 99-16-6586 E-mail: ntsomboh@yahoo.fr

G. F. Ngando Ebongue \& Koona Paul

Specialized Centre for Oil Palm, Research (IRAD-CEREPAH) of La Dibamba

P. O. Box 243 Douala, Cameroon

Bell Joseph Martin, Youmbi Emmanuel \& Ngalle Hermine B.

Faculty of Science, Department of Plant Biology,

University of Yaounde I, B. P. 812 Yaounde, Cameroon

Bilong Eloi Gervais, Madi Galdima \& Anaba Bienvenu

Specialized Centre for Oil Palm, Research (IRAD-CEREPAH) of La Dibamba

P. O. Box 243 Douala, Cameroon

Received: September 24, 2011 Accepted: October 9, 2011

doi:10.5296/jbls.v3i1.992 URL: http://dx.doi.org/10.5296/jbls.v3i1.992 


\begin{abstract}
The oil palm, Elaeis guineensis Jacq., is the most important and highest oil yielding crop in the world. Two types of oils are produced from its fruits, crude palm oil (CPO) and palm kernel oil (PKO). Palm oil is used for food purposes, oleo-chemicals, pharmaceutical purposes, health supplement and as a source of biofuel. Among the various challenges faced by farmers of this crop are diseases like Ganoderma (common in Asia), bud rot (Latin America) and vascular wilt (Africa) that affect growth and reduce oil yields. Vascular wilt caused by Fusarium oxysporum f. sp. elaeidis results in serious damages on oil palm culture in Africa. Various methods of control which have been tried against the disease are: selection of resistant or tolerant plant material, soil renewal, chemical control, stimulation of defense reactions, and the use of cover crop and potassium (K) fertilizer. The only most feasible and eco-friendly control method presently considered to be most effective against the disease is research for resistant plant material through artificial inoculation of plantlets in the pre-nursery with pathogenic fungus. Selection is based on the sensitivity of oil palm strains to the fungal inoculum. The present review outlines the importance of oil palm and the various approaches to fight against vascular wilt disease, with emphasis on biological control by the use of resistant plant material.
\end{abstract}

Keywords: Oil palm; Elaeis guineensis Jacq.; Fusarium oxysporum f. sp. elaeidis; Vascular wilt; Resistance; Disease control.

\title{
1. Introduction
}

The oil palm, Elaeis guineensis Jacq., of the family Arecaceae with chromosome number 2n $=32$ is a perennial monocot of great importance both in small-scale and large-scale farming in most countries in the world. It is the most important oil crop in the world (Oil world, 2008). Cultivated on about 9 million hectares (ha), the palm is the world's leading source of vegetable fats and oils, and the highest oil-yielding perennial crop with a potential yield of 6 to 7 tons/ha (Cochard et al., 2001), grown on a commercial scale throughout much of Malaysia and Indonesia (Hartley, 1988; Tandon et al., 2001). The oil palm is classified into 3 separate groups based on the shell thickness of its fruit: dura (thick shell), tenera (relatively thin shell) and pisifera (absence of shell). Tenera with higher oil extraction efficiency is a genetically formed hybrid between dura and pisifera (Hartley, 1988; Harminder et al., 2010).

Oil palm seed production is done following the reciprocal recurrent selection (RRS) scheme, a procedure put in place by I.R.H.O. (Institut de Recherches pour les Huiles et Oléagineux) in 1957 and adapted to oil palm (Comstock et al., 1949; Gascon \& Meunier, 1972; Cochard et al., 1993). The RRS scheme is a breeding method based on progeny tests exploiting general and specific combining abilities at the same time. The process involves quality control checks within the seed production chain taking into account the identity of the parents, the quality of male and female inflorescences' isolation and pollen quality (Cochard et al., 2001). The tenera hybrid of the second cycle of selection through RRS scheme has an average production potential of 3.5 tons of palm oil/ha/year thus making the oil palm the highest oil producing 
crop in the world (Gascon et al., 1988; Cochard et al., 1993).

The three main regions of oil palm production are Asia, Africa and Latin America (Fèvre, 2003). In 2001, Africa ranked second after Asia among world's oil producers (Boliver et al., 2003). The distinctive total palm oil yield per hectare makes it the most productive source of vegetable oil per ha of land per annum in comparison to other vegetable oil sources (Liwang, 2003). Oil Palm is the tree crop product with the strongest domestic demand in Africa (Fèvre, 2003). In 2000, the crop contributed to about $27 \%$ of world's vegetable oil production (Fold, 2003). In Cameroon, seed production by the PNRPH (Programme National de Recherche sur le Palmier à Huile) doubled from 1996 to 1999, passing from 800.000 to 1.700 .000 pre-germinated seeds (Bell, 2000) and by 2001, Cameroon produced some 159,000 tons of palm oil, thus being the third largest African producer (Fèvre, 2003).

Two types of oils are produced from the oil palm fruits, crude palm oil (CPO) extracted from the mesocarp and palm kernel oil (PKO) extracted from the kernel. Palm oil is used for food purposes (cooking oil, margarine, vanaspati, and shortenings), oleochemicals (detergents, cosmetics), pharmaceutical purposes (carotenes), health supplement and as a source of biofuel. Regular world population increase rated at about $1.7 \%$ per year (Henri, 1994) is the main reason for the constantly increasing consumption of oil palm and other vegetable oils. The steadily increasing interest in oil palm production has to be coupled with extension and improvement of the culture. Oil palm replanting and extension programmes amount to a market of around 150 million seeds per year and this high demand requires that seeds supplied to farmers be of legitimate and known heritable parameters (Cochard et al., 2001), possibly through controlled pollination (Ntsomboh, 2007). Only seeds marketed by breeders can secure the initial investment involved in setting up or renewing an oil palm plantation (Cochard et al., 2001).

Cultivated area for the oil palm (ha x 1000) increased from 3,560 to 7,950 between 1990 and 2003 (Cochard et al., 2005) consequently involving greater investments in terms of improved plant material and phytosanitary inputs. Constraints limiting the extension and profitability of oil palm cultivation are ecological (destruction of natural forests), high labor demand, and diseases. Research endeavors towards reduced inputs and increase of yields are the major preoccupations of oil palm breeders. Breeding and genetic improvement work for the crop began in the 1920s in Africa and Southeast Asia and in the 1960s, researchers launched a RRS scheme and the first selection cycle led to a 15\% increase in yields (Gascon et al., 1981; Cochard et al., 2005). In a Malaysian company and with favorable conditions, oil yields increased from 1.3 tons of oil per hectare in 1950 to 5.4 in 1990, but apparently only half the progress was due to selection (Davidson, 1991; Cochard et al., 2005). Under less suitable conditions (Ivory Coast), the planting material marketed had a yield potential of 2.9 tons of oil/ha/year in 1950 and in 1998, yield potential was 4.1 (Durand-Gasselin et al., 2000; Cochard et al., 2005).

All this work undertaken over the last 50 to 60 years has led to ongoing genetic progress estimated at $1 \%$ per year (Hardon et al., 1987; Gascon et al., 1988; Durand-Gasselin et al., 2000; Cochard et al., 2005). Future yields expected under the most suitable conditions are 
expected to reach or exceed 10 tons of oil/ha/year (Corley \& Tinker, 2003; Durand-Gasselin et al., 2003). Moreover, an international experiment set up in several countries around the world was launched for oil palm research leading to numerous exchanges of plant materials between stations in the 1970s and 80s (Gascon \& De Berchoux, 1964; Rosenquist et al., 1990; Cochard et al., 2005). All these endeavors have been geared towards the development of appropriate crop management approaches like lower cost cropping systems and non-chemical control of endemic diseases (Cochard et al., 2005). Such sustainable approaches entail exploiting plant material with an eco-agricultural long-term objective of reducing genetic erosion and any genetic vulnerability by diversifying agricultural production and increasing the genetic diversity of the plant, whilst keeping in mind the need to increase productivity. Strategies are being developed against the main pests and diseases of the oil palm such as Fusarium oxysporum f. sp. elaeidis and Ganoderma, by using sustainable genetic resistance. A genetic hence, eco-friendly approach has been taken to successfully produce vascular wilt-tolerant planting material (Cochard et al., 2005).

\section{Three Major Diseases of the Oil Palm}

The oil palm is susceptible to three more or less specific diseases on each of the three continents where it is cultivated. Vascular wilt caused by Fusarium oxysporum f. sp. elaeidis is the most damaging disease of oil palm in Africa (Renard et al., 1972; Renard \& Ravisé, 1986; Renard \& de Franqueville, 1989; Diabate et al., 1990; de Franqueville \& Diabaté, 1995; Flood, 2006; Tengoua \& Bakoumé, 2008), causing up to 70\% mortality. Several West and Central African countries are particularly affected by vascular wilt (Van de Lande, 1984; Renard \& Quillec, 1984; Renard \& Ravisé, 1986; Tengoua \& Bakoumé, 2008). Vascular wilt was observed in Latin America (Brasil) in 1983 (Van de Lande, 1984; Renard \& Ravisé, 1986; Renard \& de Franqueville, 1989) and in Ecuador. It basically spreads according to soil type, sandy soils favoring its development, but it also exists on rich volcanic soils and clay soil (Renard \& de Franqueville, 1989). It is a disease of mature palms when a plantation is set up on former savannah or forest. With immature oil palms the disease can occur right from the first year after planting, when replanting is carried out in a zone previously affected by vascular wilt (de Franqueville \& Diabate 1995; Cochard et al., 2005). In Ivory Coast, losses at the level of pre-nursery was evaluated in 1961 at about 40000 plantlets (Ravisé, 1965).

In Southeast Asia, basal stem rot has been known to cause up to $80 \%$ mortality (de Franqueville \& Renard, 1990; de Franqueville et al., 2001; Cochard et al., 2005). This disease is caused by Ganoderma, a soil borne fungus that attacks palm oil roots. No control method against this disease has so far been really efficient. Differences in the behavior of palm lines towards basal stem rot suppose that there exist palm lines that are resistant to this fungus (Noiret \& Quencez, 1992).

In Latin America, a bud rot disease of unknown origin causes up to $100 \%$ mortality. For these three cases of oil palm diseases, genetic control strategies are being developed.

\section{Expansion of the Culture and the Need for Improved Planting Material}

The expansion of oil palm culture both by the agro-industrial and smallholder sectors 
demands production of more seeds. Moreover, oil palm breeders must continue to improve its yields, given the continuously increasing demand for fats and oils and the substantially reduced possibility of increasing the areas planted to oil palm. Many centres are involved in intensive seed production and the incidence of parasites in pre-nurseries is observed almost everywhere with variable importance. Oil palm being a perennial crop whose culture is intended to last 25 to 30 years, plant breeders need to produce good quality planting material by guaranteeing its legitimacy, high yields, resistance to the main diseases and be able to advise on the most appropriate material for a given pedoclimatic environment. There is thus the need to pursue genetic control of the different diseases, focusing on durable resistance, as is the case for vascular wilt with many years of proven resistance (Cochard et al., 2005; Flood, 2006).

\section{Resistance Mechanism and Symptoms of Vascular Wilt Disease}

\subsection{The Mechanism of Oil Palm Resistance against Vascular Wilt}

The fungus Fusarium oxysporum f. sp. elaeidis which causes vascular wilt disease is specific to oil palm and is one of the several parasitic microorganisms isolated from oil palm plantlets. The morphology and anatomy of this parasite have been described by Ravisé (1965). The parasite is easily isolated from brown fibres in the stem or the leaf petioles. It has the same characteristics as all of the Fusarium oxysporum fungi: macroconidia, microconidia and chlamydospores (Flood, 2006).

Pure cultures of Fusarium oxysporum are generally salmon-pink. When oil palm seedlings are inoculated with the cultures, symptoms of the disease are reproduced (Fraselle, 1951; Renard \& Ravisé, 1986; Renard \& de Franqueville, 1989). The pathogen penetrates the roots, develops in the xylem vessels, and causes gum and thyloses which block the vessels (Flood, 2006). This disruption of the vascular system leads to death or unproductiveness of the palm (Tengoua \& Bakoumé 2008). Physiological modifications occur from the first week following inoculation of plants from oil palm strains tolerant to vascular wilt (Taquet, 1985; Renard \& Ravisé, 1986), and persist throughout the testing period in the nursery or greenhouse. Research on defense mechanisms of the oil palm in reaction to Fusarium oxysporum $f$. sp. elaeidis has revealed the production of phytoalexines by the plant. Some inhibitory substances secreted by the plant against the parasite accumulate in the tissues of the roots and pseudo bulbs of resistant plants in vitro (Renard \& Ravisé, 1986; Diabate et al., 1990). These substances result from two biosynthetic pathways: the acetyl Coenzyme A pathway which produces lipid derivatives, and the shikimic acid pathway towards phenolic compounds. The latter pathway seems to be the most stimulated. Particularly, derivatives of benzoic acid, cinnamic acids and their derivatives, and flavonoids accumulate in tissues. In addition, inhibitory properties of the resistance factors have been verified in vitro for germination of the parasite spores (Renard \& Ravisé, 1986).

\subsection{Oil Palm Vascular Wilt Symptoms}

The symptoms triggered by Fusarium oxysporum were first described by Wardlaw (1946a, 1946b). Later on, the disease was observed in numerous plantations in Congo, then in Nigeria, 
Cameroon, Ivory Coast, and throughout West Africa (Renard et al., 1972; Renard \& Ravisé, 1986; Renard \& de Franqueville, 1989; Cochard et al., 2005). Visible symptoms of oil palm vascular wilt are extremely varied. The symptoms basically depend on the age of the plant, the stage of infection, susceptibility of the plant material and environmental factors (Renard \& Ravisé, 1986; Renard \& de Franqueville, 1989). Nonetheless, there is clear distinction between symptoms at the level of nursery palms, 1-4 year-old palms and productive palms (Renard \& Ravisé, 1986). Two forms of symptoms are usually observed on vascular wilted palms (Renard, 1979; Flood, 2006): the typical or acute symptoms through which the palm dies three to four months after their appearance, and the chronic symptoms which maintain the palm alive, weaken and render it almost unproductive (Tengoua \& Bakoumé, 2008). The basic procedures for identifying vascular wilt on plants are defined by Renard \& de Franqueville (1989).

Oil palm vascular wilt can be triggered by inoculating young oil palm plantlets (1-leaf stage) with symptoms appearing about 8 weeks after inoculation. Infected seedlings show brown vessels in dissected bulbs and exhibit stunting, yellowing and perforation of leaves (Tengoua \& Bakoumé, 2008). However, the yellowing of one or several leaves, concentrated in one section of the crown, can be confused with Rhynchophorus attack. This can be checked by dissecting the stem, the presence of Rhynchophorus larvae being proved either by a scratching noise in the stem or, by fibre scraps on the ground (Renard \& de Franqueville, 1989).

In the most unfavorable conditions for first generation plantations, vascular wilt occurs earliest 7 to 8 years after planting. The first symptoms on forest land do not generally appear before the age of 6-7, and sometimes 10. On new growth and food crops, and on impoverished soil, the disease may develop earlier. In replanting, in non-infected areas, it develops from 6-7 years (Renard \& Ravisé, 1986). In infected areas, the disease may develop right from the first year after planting (Renard \& de Franqueville, 1989; Renard \& Ravisé, 1986). For susceptible plant material and in replantation on infected zones, the disease appears 1 to 2 years after planting and evolves at the rate of about $2 \%$ infected plants per year (Renard \& Ravisé, 1986). Vascular wilt disease is very rare in the nursery, and is exceptional at the pre-nursery stage.

\subsection{Damages Caused by Oil Palm Vascular Wilt}

By 1986, vascular wilt concerned about 600000 hectares of palm plantations in Africa (Renard \& Ravisé, 1986). Yield losses due to vascular wilt range between 25\% and 50\% and even more (Renard \& Ravisé, 1986; Flood 1986; Tengoua and Bakoumé 2008). In Zaire, the average of dead or dying palms on ten-year-old plantations was as high as $25 \%$ (Guldentops, 1962). In Cameroon, vascular wilt is responsible for $42 \%$ of vacancies in oil palm plantations (Tengoua and Bakoumé, 2005; Tengoua and Bakoumé, 2008). On the I.R.H.O.'s R. Michaux experimental plantation at Dabou, the mean annual percentage of palms attacked by wilt was $1 \%$ (Renard et al., 1972).

Wild oil palm groves suffer little from vascular wilt as compared with severe damages on plantations (Renard \& de Franqueville, 1989). The damage caused by the disease depends 
upon at least three factors (Renard \& de Franqueville, 1989): the genetic origin of the planting material (most important factor in the occurrence of the disease); the previous crop (on primary forest, the disease appears late, whilst on soils impoverished by previous crops, and in second generation oil palm, vascular wilt can develop rapidly); and crop techniques. Under the most favorable conditions (susceptible planting material, in an area predisposed to the disease), up to $50 \%$ of the trees may be affected (Renard \& de Franqueville, 1989). In the most unfavorable conditions (uninfected soil with resistant plant material) for first generation plantations, cumulated losses are less than $1 \%$ of trees per year. Loss in yield due to vascular wilt is about $0.9 \%$ in weight for $1 \%$ of trees infected. In infected plantations, yield loss can reach about $30 \%$ between 15 and 20 years. Some palm strains have presented $25 \%$ infected trees in eight years (Renard \& de Franqueville, 1989).

\section{Control Methods against Vascular Wilt of the Oil Palm}

Several methods to fight vascular wilt of the oil palm have been envisaged with variable results. These include four major approaches: selection of tolerant material; soil renewal and chemical control; stimulation of oil palm defense reactions; and the use of cover crop and fertilizer. So far, the most efficient control measure is basically preventive and on a planting material selection level (Renard \& de Franqueville, 1989).

\subsection{Selection of Tolerant Material}

Vascular wilt of the oil palm is considered to be a disease of young age in plantations and as such, it is essential to intervene as earliest as possible to reduce the risk of contamination of young plants (Renard \& Quillec, 1983; Renard \& Ravisé, 1986). Replanting in affected areas require the use of planting material whose tolerance has been proved by tests at the pre-nursery stage and confirmed by its performance in the field (Renard \& de Franqueville, 1989; Renard et al., 1972; Renard et al., 1980; Renard \& Meunier, 1983). Research for resistant material is so far the only effective means of fighting vascular wilt disease of the oil palm. Observations in the field and the contamination of young plants with Fusarium oxysporum have shown at a very early stage that clear and significant differences in susceptibility exist among palm strains (Renard et al., 1972), with certain crosses being more tolerant of the disease than others (Taquet et al., 1985; Renard \& Ravisé, 1986). This has been the basis for a program initiated to improve resistance of plants against the disease within the general oil palm improvement program based on RRS (Renard \& Ravisé, 1986; Meunier \& Gascon, 1972). Based on these observations, control methods have been geared towards improving resistance to the disease (Renard et al., 1972; Renard \& de Franqueville, 1989).

Renard et al. (1972) and Prendergast (1963) have paved the way with appropriate methods for testing oil palm progenies at nursery stage for resistance against the disease. The selection process is based essentially on the performance of the crosses with respect to vascular wilt, administered at the pre-nursery stage by artificial inoculation. An early test has been establishment to appreciate the sensitivity of oil palm strains (Renard et al., 1972; Renard \& Ravisé, 1986) according to which the performance of a strain is defined by an index $(I)$ in relation to the mean percentage of wilt-stricken plants in the whole of one test. Thus, the (I) 
value for each strain (say strain A) is obtained by the following formula (Renard et al., 1972):

$$
I=\frac{\% \text { wilt of infected plants of strain } A}{\% \text { wilt of infected plants in all strains }} \times 100
$$

The oil palm strain with low index is the most resistant to wilt, and it can be accepted that a satisfactory estimate of the threshold for a strain said to be resistant lies at the mean index 100 .

\subsection{Field Management and Chemical Control}

\subsubsection{Field Management}

The control of oil palm vascular wilt by soil renewal is certainly very expensive. The method consists of renewing the pre-nursery soil each year; forest soils are a priori fertile and exempt or lightly infested by parasites (Ravisé, 1965). The choice of planting site is also an important factor to be considered for replanting (Renard \& Quillec, 1983). Moreover, better field management like planting new palms more than $2 \mathrm{~m}$ from old stumps can reduce the disease incidence by half (Renard \& de Franqueville, 1991; Flood, 2006).

\subsubsection{Chemical Control}

No satisfactory chemical method to fight against vascular wilt presently exists. In the 1960s, chemical control methods used against vascular wilt disease proved to be expensive and ineffectual. The location of the parasite both in the soil and in the plant renders it difficult to fight against the disease and the application of fungicide is expensive for large areas (Renard \& Ravisé, 1986). However, disinfection of the nursery with an alkyl mercury solution or ethylene bis-dithiocarbamate zinc, ten days before planting is recommended. The former, though a powerful fungicide is slightly toxic to the oil palm. The latter only inhibits the development of parasites and is inoffensive to the oil palm. A preventive measure could be to soak plantlets in a $15 \mathrm{mg}$ solution of alkyl mercury per litre of water for five minutes before planting in the pre-nursery (Ravisé 1965).

\subsection{Stimulation of Oil Palm Defense Reactions}

\subsubsection{Stimulation by Premonition}

In the pre-nursery, the tolerance index for vascular wilt disease can be improved by premonition. The technique consists in inoculating plants with a non virulent strain of Fusarium oxysporum $f$. sp. elaeidis ten days before infection with the virulent parasite. Additional research has been carried out to detect resistance factors involved, with a view of improving selection (Renard \& Ravisé, 1986; Renard \& de Franqueville, 1989). Comparative analysis of plant tissues inoculated and of those that went through premonition before inoculation revealed in the latter higher contents of phenolic compounds and greater accumulation of resistance factors (Taquet et al., 1983; Renard \& Ravisé, 1986; Vernenghi et 
al., 1987).

By premonition, the tolerance of a palm strain passes from $75 \%$ to $95 \%$ uninfected plants and the composition of phenolic compounds increases by about $20 \%$ in the tissues. Quantitative variations of the contents of phenolic compounds are determined following the premonition ability of Fusarium oxysporum $f$. sp. elaeidis strains from the soil or isolated from palm tissues. By analogy with presumed premonition mechanisms, fungicide elicitors like hexose amines and arachidonic acid are applied to different palm strains before, during or after experimental inoculation. In the presence of the parasite, these substances stimulate the synthesis of resistance factors. These activities concern palms that are tolerant to vascular wilt. Comparison of the effect of application of an inhibitor of phenols synthesis, $\alpha$-oxyamino acetic acid, to that of an elicitor (arachidonic acid) helps to affirm that it is an active reaction of the plant (Renard \& Ravisé, 1986). In vitro toxicity tests are realized on extracts of corresponding tissues to confirm analytic results. A correspondence between observations in the pre-nursery of vascular wilt index of palm strains and the analytic results provide for two complementary tools for the appreciation of tolerance of various crosses. This method, with other elicitor products can enhance the search of a curative method at the start of infection (Renard \& Ravisé, 1986).

\subsubsection{Petiole Infusion Technique}

Petiole infusion technique is a further development to aid screening for resistance which equally helps to study the host-pathogen interaction. This technique allows a nondestructive assessment of the resistance of individual palms in only a few days, with the possibility of using the selected palm as a parent for breeding. The petiole technique which has been tested in the field is also useful for investigating the production of antifungal compounds in the oil palm (Pepsted et al., 1995; Corley \& Tinker, 2003; Flood, 2006). It could be interesting to envisage the use of antagonistic micro organisms or fungicidal plant extracts against vascular wilt since these approaches have proven their efficiency on other plants like ground nuts (Ambang et al., 2008).

\subsection{Use of Cover Crop and Fertilizer}

Another control measure against vascular wilt of the oil palm could be the use of cover crop or potassium (K) fertilizer. Calapogonium caeruleum (a cover crop) favors the development of vascular wilt. Pueraria, another cover crop, is more suitable against the wilt disease (Renard \& Ravisé, 1986; Renard \& de Franqueville, 1989). Low K fertilizer contents favor the development of vascular wilt of the oil palm (Ollangnier \& Renard, 1976; Renard \& Ravisé, 1986; Renard \& de Franqueville, 1989). It has been found from leaf diagnosis that yield losses for first generation plantations are reduced by good potassium manure (Renard \& Ravisé, 1986)

\section{Conclusion}

The search for vascular wilt resistant palms is so far the most efficient control method against vascular wilt of the oil palm following the discovery in the 1960s of resistant crosses of oil palm in plantations. An early screening method developed to assess the performance of 
materials (Prendergast, 1963; Renard et al., 1972; Cochard et al., 2005) has proved possible to define sources of resistance (Renard et al., 1980; Cochard et al., 2005) and to define commercial hybrids displaying disease tolerance (Renard \& Meunier, 1983). This methodology which is widely used helps to substantially reduce the impact of the disease (Flood, 2006). This resistance has proved to be durable, since it has been used successfully for so many years. A vascular wilt resistance breeding program now aims at diversifying the genetic base since all the populations have sources of resistance (Durand-Gasselin et al., 2000; Cochard et al., 2005).

\section{References}

Ambang, Z., Ndongo, B. B., Ngoh, D., Maho, Y., \& Ntsomboh, G.. (2008). Effect of mycorrhizal inoculum and urea fertilizer on diseases development and yield of groundnut crops (Arachis hypogaea L.). Afr. J. Biotechnol., 7 (16), 2823-2827.

Bell, J. M. (2000). Evaluation de l'offre en graines de palmier à huile sélectionné au Cameroun. Vol. I: Rapport principal. A.F.V.P., Yaoundé. 85 p.

Bolivar, E., \& Cuellar-Mejia, M. (2003). Oil palm in South America: Evolution of the Latin American oil palm sector 1991-2001. Burotrop 19, 19-24.

Cochard, B., Adon, B., Kouame, K. R., Durand-Gasselin, T., \& Amblard, P. H. (2001). Intérêts des semences commerciales améliorées de palmier à huile (Elaeis guineensis Jacq.). OCL, 8, 654-658.

Cochard, B., Amblard, P., \& Durand-Gasselin T. (2005). Oil palm genetic improvement and sustainable development. OCL, 12 (2), 141-147.

Cochard, B., Noiret, J. M., Baudouin, L., Flori, A., \& Amblard, P. (1993). Second cycle reciprocal recurrent selection in oil palm, Elaeis guineensis Jacq. Results of Deli x La Mé hybrid tests. Oléagineux, 48 (11), 441-451.

Comstock, R. E., Robinson, H. F., \& Harvey, P. H. (1949). A breeding procedure designed to make maximum use of both general and specific combining ability. Agron. J., 41, p. 360.

Corley, R. H. V., \& Tinker, B. (2003). The oil palm. 4th edition. Oxford: Blackwell Science Ltd, 562p.

Davidson, L. (1991). Management for efficiency, cost effective and productive oil palm plantations. In Basiron (Ed), Proc 1991 Porim International Palm Oil Conference- Palm Oil Res. Int. Malaysia, Kuala Lumpur, 1993. Agriculture, 153-67.

De Franqueville, H., \& Diabate, S. (1995). La fusariose du palmier à huile en Afrique de l'ouest. Plantation Recherche Développement, 24, 5-13.

De Franqueville, H., \& Renard, J. L. (1990). Improvement of oil palm vascular wilt tolerance. Results and development of the disease at the R. Michaux plantation. Oléagineux, 45, 399-405.

De Franqueville, H., Asmady, H., Jacquemard, J. C., Hayun, Z., \& Durand-Gasselin, T. 
(2001). Indications on sources of oil palm (Elaeis guineensis Jacq.) genetic resistance and susceptibility to Ganoderma sp, the cause of basal stem rot. In: Proc 2001 Int. Palm Oil Congr., Malaysian Palm Oil Board, Kuala Lumpur. Agriculture, pp. 420-431.

Diabate, S., Taquet, B., Renard, J. L., de Franqueville, H., \& Reiser, P. (1990). HPLC analysis of substances produced by oil palm and implicated in resistance to Fusarium oxysporum $\mathrm{f}$. sp. elaeidis: prospects for selection. Oléagineux, 45 (2), 49-55.

Durand-Gasselin, T., de Franqueville, H., \& Hayun, Z. (2003). Is it possible and reasonable to produce 10 tons of oil per hectare of oil palm? ISOPB, Medan, 6-9 October 2003.

Durand-Gasselin, T., de Franqueville, H., Diabate, S., Cochard, B., \& Adon, B. (2000). Assessing and utilizing sources of resistance to Fusarium wilt in oil palm (Elaeis guineensis Jacq.) genetic resource. Int. Symp "Oil palm genetic resources and utilization", 8-10 June 2000. Malaysian Palm Oil Board, Kuala Lumpur.

Durand-Gasselin, T., Kouame, K. R., Cochard, B., Adon, B., \& Amblard, P. (2000). Diffusion variétale du palmier à huile (Elaeis guineensis Jacq.). OCL, 7, 203-206.

Fèvre, E. (2003). The oil palm sector in Cameroon. Re-investing in smallholder farming systems. Burotrop, 19, 51-52.

Flood, J. (1986). Resistance of oil palm (Elaeis guineensis Jacq.) to Fusarium wilt. In Proceedings of 2nd Int. Conf. Pl. Prot. in the tropics. Kuala Lumpur, Malaysia, pp. 70-72.

Flood, J. (2006). A review of Fusarium wilt of the oil palm caused by Fusarium oxysporum $\mathrm{f}$. sp. elaeidis. Phytopathology, 96 (6), 660-662.

Fold, N. (2003). Oil palm markets and trade. Burotrop, 19, 11-13.

Fraselle, J. V. (1951). Experimental evidence of the pathogenicity of Fusarium oxysporum Schl. f. to the oil palm (Elaeis guineensis J.). Nature, 167, 447.

Gascon, J. P., Jacquemard, J. C., Houssou, M., Boutin, D., Chaillard, H., \& Kamga, F. F. (1981). La production de semences sélectionnée de palmier à huile Elaeis guineensis. Oléagineux, 36, 476-486.

Gascon, J. P., \& De Berchoux, C. H. (1964). Caractéristiques de diverses origines et leurs croisements. Application à la sélection du palmier à huile. Oléagineux, 19, 75-84.

Gascon, J. P., \& Meunier, J. (1972). Le schéma général d'amélioration du palmier à huile à l'IRHO. Oléagineux, 27 (1), 1-12.

Gascon, J. P., Le Guen, V., Nouy, B., Asmady, \& Kamga, F. F. (1988). Results of second cycle recurrent reciprocal selection trails on oil palm Elaeis guineensis Jacq. Oléagineux, 43, $1-7$.

Guldentops, R. E. (1962). Contribution à l'étude de la trachéomycose du palmier à huile. Parasitica, 18, 244-263.

Hardon, J. J., Corley, R. H. V., \& Lee, C. H. (1987). Breeding and selecting the oil palm. In A. 


\section{MInstitute Macrothink}

J. Abott \& R. K. Atkin (eds), Improving vegetatively propagated crops. London Academic Press, pp. 63-81.

Harminder, S., Rajinder, Singh, Abduh, R., Rahimah, Ooi, Cheng, Li, Low, Eng, \& Ti (2010). Method for identification of a molecular marker linked to the shell gene of oil palm. PCT/MY2009/000192, International application published under the Patent Cooperation Treaty (PCT), World Intellectual Property Organization International Bureau. International publication, 33p. Retrieved from the Internet at:

http://www.sumobrain.com/patents/wipo/Method-identification-molecular-marker-linked/WO 2010056107A2.pdf (November 3, 2010)

Hartley, C. W. S. (1988). The oil palm (Elaeis guineensis Jacq.), 3rd ed. Longman scientific and technical Essex, UK. 761 p.

Henri, G. R. (1994). Tendances du marché mondial des huiles et graisses alimentaires. Oléagineux Corps gras Lipides, 1 (1).

Liwang, T. (2003). Oil palm in Asia: Organization of the oil palm commodity chain. Burotrop, 19, 25-29.

Meunier, J., Gascon, J. P. (1972). Le schéma général d'amélioration du palmier à huile à l'IRHO. Oléagineux, 27 (1), 1-12.

Meunier, J., Renard, J. L., \& Quillec, G. (1979). Heredity of resistance to Fusarium wilt in the oil palm Elaeis guineensis Jacq. Oléagineux, 34, 555-561.

Noiret, J. M., \& Quencez, P. (1992). Etude de faisabilité d'un projet de renforcement de la recherche appliqué à l'élaeiculture au Cameroun. Rapport provisoire (IRAD) $\mathrm{N}^{\circ}$ doc: 2434 , $104 p$.

Ntsomboh, G. N. (2007). Fruit status of the oil palm (Elaeis guineensis Jacq. var. pisifera) in controlled pollination. Master's with thesis (DEA) in Plant Biotechnology. University of Yaounde1, 45p.

Oil world annual report (2008).

Ollangnier, M., \& Renard, J. L. (1976). Influence du potassium sur la résistance du palmier à huile à la fusariose (Bilingue fr. -angl.). Oléagineux, 31 (5), 203-209.

Pepsted, R., Flood, J., Paul, T. C., Airede, C., \& Cooper, R. M., (1995). A model system for rapid selection of resistance and for investigation of resistance mechanism in Fusarium wilt of oil palm. Plant Pathol., 44, 749-755.

Prendergast, A. G. (1963). A method of testing oil palm progenies at the nursery stage for resistance to vascular wilt disease caused by Fusarium oxysporum, Schl. J W Afr Inst Oil Palm Res, 4, 156-175.

Ravisé, A. (1965). Etude de parasites de plantules d'Elaeis guineensis en prépepinière. In Congrès de la protection des cultures tropicales, Marseille, pp. 801-806. 
Renard J. L., de Franqueville H. (1989). Oil palm vascular wilt. Oléagineux, 44 (7), 341-349.

Renard, J. L. (1979). Vascular wilt disease (Fusarium) in the oil palm. Diagnoses on the plantation. Control measures. Oléaginuex, 27 (12), 581-591.

Renard, J. L., \& de Franqueville, H. (1991). Effectiveness of crop techniques in the integrated control of oil palm vascular wilt disease. Oléagineux, 46, 255-265.

Renard, J. L., \& Quillec, G. (1983). Fusariose et replantation de palmiers à huile en zone fusariée en Afrique de l'ouest (trilingue fr. -angl. -esp). Conseil de l'IRHO No 235. Oléagineux, 387, 421-427.

Renard, J. L., \& Quillec, G. (1984). Les maladies graves du palmier à huile en Afrique et en Amérique du Sud. Oléagineux, 39 (2), 57-67.

Renard, J. L., \& Ravisé, A. (1986). La fusariose du palmier à huile. Phytoma, 374, 44-46.

Renard, J. L., de Franqueville, H. (1989). Oil palm vascular wilt. Oléagineux, 44 (7), 341-349.

Renard, J. L., Gascon, J. P., Bachy, A. (1972). Recherches sur la fusariose du palmier à huile (Bilingue fr. -angl.). Oléagineux, 27 (12), 581-591.

Renard, J. L., Meunier, J. (1983). Research for durable resistance to vascular wilt disease (Fusarium oxysporum f. sp. elaeidis) of oil palm (Elaeis guineensis). In F. Lamberto, J. M. Waller \& N. A. Van der Graaf (eds). Durable Resistance in Crops. Plenum Publishing Corporation, pp. 297-290.

Renard, J. L., Noiret, J. M., Meunier, J. (1980). Sources et gammes de résistance à la fusariose chez le palmier à huile Elaeis guineensis et Elaeis melanococca (Bilingue fr. angl.). Oléagineux, 35 (8-9), 387-393.

Rosenquist, E. A., Corley, R. H. V., De Greef, W. (1990). Improvement of tenera populations using germplasm from breeding programmes in Cameroon and Zaire. In Proc of the workshop on progress of oil palm breeding population. Palm oil research Institute of Malaysia, pp. 37-69.

Tandon, R., Manohara, T. N., Nijalingappa, B. H. M. \& Shivanna, K. R. (2001). Pollination and pollen-pistil interaction in Oil Palm, Elaeis guineensis. Annals of Botany, 87, 831-838.

Taquet, B. (1985). Les mécanismes physiologiques de la réaction de défense du palmier à huile contre la fusariose vasculaire. Application à la recherche de nouveaux moyens de lutte. Thèse de 3e cycle, Université de Paris VI, 151p.

Taquet, B., Ravisé, A., Renard, J. L., Kunesch, G. (1985). Modulation de réactions de défense du palmier à huile contre le Fusarium oxysporum f. sp. elaeidis (Schlecht) Toovey. Applications : prémunition et stimulation chimique. Phytopath. Z., 112, 298-314.

Taquet, B., Renard, J. L., \& Ravisé, A. (1983). Contribution de la prémunition d'Elaeis guineensis à la tolérance à Fusarium oxysporum f. sp. elaeidis. Comm. Au 25e coll. de la Sté 


\section{Macrothink}

Fse de Phytopathologie, Toulouse 18 nov. 1983; résumé. Agronomie, 7, 108.

Tengoua, F. F., \& Bakoumé, C. (2008). Pathogenicity of Cameroon strains of Fusarium oxysporum f. sp. elaeidis - the causal agent of oil palm vascular wilt. The Planter, 84 (985), 233-237.

Tengoua, F. F., \& Bakoumé, C. (2005). Basal stem rot and vascular wilt, two threats for the oil palm sector in Cameroon. The Planter, 81 (947), 97-105.

Van de Lande, H. L. (1984). Vascular wilt disease of the oil palm (Elaeis guineensis Jacq.). Para Brasil Oil Palm News, 28, 6-10.

Vernenghi, A., Taquet, B., Renard, J. L., \& Ravisé, A. (1987). Détection chez le palmier à huile de dérivés oxygénés d'acides gras polyéniques toxiques pour le Fusarium oxysporum f. sp. elaeidis ; variation de leur accumulation selon les croisements et les modalités de traitement. Oléagineux, 42 (1), 1-10.

Wardlaw, C. W. (1946a). A wilt disease of the oil palm. Nature, 158, p. 56.

Wardlaw, C. W. (1946b). Fusarium oxysporum on the oil palm. Nature, 158, p. 712.

\section{Copyright Disclaimer}

Copyright reserved by the author(s).

This article is an open-access article distributed under the terms and conditions of the Creative Commons Attribution license (http://creativecommons.org/licenses/by/3.0/). 